\title{
KONDISI LANJUT USIA YANG MENGALAMI HIPERKOLESTEROLEMIA DI POS PELAYANAN TERPADU ( POSYANDU ) LANJUT USIA DESA BETENGSARI, KARTASURA : PILOT STUDY
}

\author{
Widiyono ${ }^{*}$, Atik Aryani ${ }^{1}$, Vitry Dyah Herawati ${ }^{1}$ \\ ${ }^{1}$ Prodi Ilmu Keperawatan, Universitas Sahid Surakarta \\ *korespodensi email :widiyono2727@gmail.com
}

\begin{abstract}
ABSTRAK
Latar belakang: Hiperkolesterolemia berhubungan dengan bertambahnya usia dan merupakan faktor utama yang dapat menyebabkan penyakit kardiovaskular. Kejadian hiperkolesterolemia pada lansia berhubungan dengan asupan makanan berlemak dan faktor lainnya. Dampak hiperkolesterolemia adalah 80\% pasien meninggal mendadak akibat serangan jantung. Tujuan: Mengetahui gambaran kondisi lansia yang mengalami hiperkolesterolemia di Posyandu lansia Desa Betengsari, Kartasura. Metode: Penelitian yang digunakan adalah deskriptif analitik dan merupakan pilot study. Total jumlah sampel adalah 29 responden. Pengambilan sampel dilakukan dengan teknik purposive sampling. Instrumen untuk mengukur kadar kolesterol adalah GCU (Glukosa Colesterol Urid acid) merk EasyTouch. Hasil: semua responden memiliki riwayat kolesterol tinggi,, sebanyak 23 respponden $(79,3 \%)$ berjenis kelamin perempuan, sebanyak 26 responden $(89,7 \%)$ memiliki pola makan diet lemak jenuh, sebanyak 29 responden (100\%) melakukan aktivitas fisik olah raga dan sebanyak 3 responden (10,3\%) memiliki kebiasaan merokok. Kesimpulan penelitian ini $100 \%$ lansia memiliki riwayat kolesterol tinggi. Saran diperlukan intervensi yang tepat untuk mengatasi hiperkolesterolemia. Selain pemberian terapi farmakologi (obat normolipidemia), perawat dapat memberikan terapi komplementer herbal yaitu rebusan daun salam yang terbukti efektiv untuk mengurangi kadar kolesterol dalam darah.
\end{abstract}

Kata kunci : lanjut usia, hiperkolesterolemia, posyandu lansia

\section{ABSTRACT}

Background: Hypercholesterolemia is associated with increasing age. It is a major factor caused cardiovascular disease. The incidence of hypercholesterolemia in the elderly is related to the intake of fatty foods and other factors. The impact of hypercholesterolemia showed that 80\% of patients die suddenly from a heart attack. Objective: Knowing the description of the condition of the elderly who experience hypercholesterolemia at the Posyandu for the elderly in Betengsari Village, Kartasura. Methods: The research used is descriptive analytic and is a pilot study. The total number of samples was 29 respondents. The sample was taken by using purposive sampling technique. The instrument for measuring cholesterol levels is the 
EasyTouch brand GCU (Glucose Cholesterol Urid acid). Results: all respondents had a history of high cholesterol, 23 respondents (79,3\%) were female, 26 respondents $(89,7 \%)$ had a saturated fat diet, 29 respondents (100\%) did physical activity. body and as many as 3 respondents (10,3\%) have smoking habits. The conclusion of this study is that $100 \%$ of the elderly have a history of high cholesterol. Suggestions are needed for appropriate interventions to overcome hypercholesterolemia. In addition to providing pharmacological therapy (normolipidemia drug), nurses can provide complementary herbal therapy, namely bay leaf decoction which has been proven to be effective in reducing cholesterol levels in the blood.

Key words: elderly, hypercholesterolemia, elderly posyandu

\section{PENDAHULUAN}

Semakin bertambahnya usia maka kondisi kesehatannya juga akan semakin menurun karena proses degenerasi. Tandatanda degenerasi disertai dengan adanya gangguan fungsi alat-alat tubuh, kemunduran kemampuan kerja panca indera, perubahan psikologi serta adanya berbagai penyakit yang muncul (Widianti \& Proverawati, 2010). Ketika masih muda tubuh masih memiliki cadangan sehingga organ masih memberikan reaksi toleransi untuk mengatasi kelainan yang terjadi. Sebaliknya, pada lanjut usia (lansia) kemampuan toleransi sudah berkurang, terlihat gejala yang berat sehingga memerlukan penanganan khusus (Bangun, 2009).

Kecepatan metabolisme pada lansia menurun sekitar 15 sampai $20 \%$, disebabkan karena berkurangnya masa otot. Fakta ilmiah menyebutkan bahwa otot menggunakan lebih banyak energi daripada lemak, sehingga lemak menjadi lebih banyak tertimbun di dalam tubuh (Zuhroiyyah et all, 2017). Jika pemakaian energi menurun, maka makanan yang harusnya dibentuk menjadi energi akan diubah menjadi kolesterol. Sudah banyak penelitian yang dilakukan untuk mengetahui hubungan aktivitas fisik dengan kadar kolesterol (Whitney \& Rolfes, 2015).

Hal inilah yang menyebabkan kelompok lansia banyak mengalami asalah sirkulasi darah dan gangguan metabolisme hormonal. Salah satunya adalah kolesterol tinggi. Kolesterol didefinisikan sebagai salah satu komponen lemak yang terdapat dalam makanan dan tubuh. Hiperkolesterolemia adalah suatu kondisi dimana meningkatnya konsentrasi kolesterol dalam darah yang melebihi nilai normal. Dikatakan hiperkolesterolemia apabila jumlah kolesterol total dalam tubuh >200 mg/dl. (Guyton dan Hall. 2014).

Masyarakat umumnya masih menganggap kolesterol tinggi pada lansia itu hal yang biasa. Kolesterol telah terbukti mengganggu dan mengubah struktur pembuluh darah yang mengakibatkan gangguan fungsi endotel yang menyebabkan lesi, plak, oklusi, dan emboli. Selain itu juga kolesterol diduga bertanggung jawab atas peningkatan stress oksidatif (Stapleton, 2010) Salah satu masalah utama pada hiperkolesterol adalah bahwa dampak yang di temukan $80 \%$ pasien meninggal mendadak akibat serangan jantung, dan 50\%-nya tidak menampakkan gejala sebelumnya (Sandiyani, 2012). 
Prevalensi penyebab kematian akibat tingginya kolesterol tertinggi terjadi pada Akut Miokard Infark (AMI) 2 (15,49\%), gagal jantung $(15,42 \%)$ dan penyakit jantung lainnya $(14,37 \%)$ (Depkes, 2013). Laporan rumah sakit dan puskesmas menunjukkan, prevalensi kasus PJK di Provinsi Jawa Tengah mengalami peningkatan rata-rata sbesar $0,31 \%$ per tahun (Depkes, 2014).

Kejadian hiperkolesterolemia pada kelompok lansia selain berhubungan dengan karena faktor usia, juga karena jenis kelamin, adanya riwayat kolesterol sebelumnya, asupan makanan berlemak dan berkolesterol tinggi (pola makan), aktivitas fisik, tingkat pendidikan, pekerjaan, Indeks Massa Tubuh (IMT) dan juga status merokok (Sari et all, 2014; Septianggi et all, 2013; Zuhroiyyah et all, 2017).

Pemerintah Indonesia telah memberikan perhatian serius dalam pencegahan dan penanggulangan penyakit tidak menular. Hal ini dapat dilihat dengan dibentuknya Direktorat Pengendalian Penyakit Tidak Menular berdasarkan Peraturan Menteri Kesehatan No. 1575 Tahun 2005 dalam melaksanakan pencegahan dan penanggulangan penyakit jatung dan pembuluh darah termasuk hiperkolesterolemia (Depkes RI, 2013 dalam Puspito, 2014). Mencermati dampak buruk dari hiperkolesterolemia maka perlu intervensi yang tepat dengan mengetahui gambaran kondisi lansia hiperkolesterol. Penelitian ini untuk mengetahui gambaran kondisi lansia yang mengalami hiperkolesterolemia di posyandu lanjut usia desa Betengsari, Kartasura.

\section{METODE}

Penelitian ini menggunakan desain deskriptif analitik dengan pendekatan studi potong lintang (cross sectional) dan menggunakan data primer yang merupakan pilot study. Penelitian ini dilakukan di Posyandu Lansia di Desa Betengsari, Pucangan, Kecamatan Kartasura, Kabupaten Sukoharjo termasuk dalam wilayah kerja Puskesmas Kartasura 1 dan dilakukan pada Februari 2020. Total jumlah sampel adalah 29 responden. Pengambilan sampel dilakukan dengan cara non probability sampling dengan teknik purposive sampling. Adapun kriteria inklusi penelitian ini adalah Lansia berumur 60 tahun (Depkes, 2013) dan Kadar kolesterol total antara 200-239 $\mathrm{mg} / \mathrm{dl}$ atau lebih. Sedangkan kriteria eksklusinya adalah responden yang mengalami gangguan ginjal dan stroke.

Pada penelitian ini instrumen untuk mengukur kadar kolesterol adalah GCU (Glukosa Colesterol Urid acid) merk EasyTouch yang sudah dikalibrasi dan memiliki akurasi yang baik.. Intrumen untuk mengukur proses biologis tubuh seperti spignomanometer, stetoskop, timbangan berat badan, alat chek GDS, kolesterol, dan asam urat biasanya telah diakui validitasnya dan reliabilitasnya (kecuali telah rusak dan tidak dilakukan kalibrasi).

Penelitian ini merupakan penelitian yang melibatkan makhluk hidup sehingga diperlukan Ethical Clearence. Penelitian ini telah sesuai standar WHO 2011 dan mendapatkan izin uji layak etik, dari Komisi Etik Penelitian Kesehatan Universitas Aisyah Yogyakarta dengan no.EC 1493/KEP-UNISA/III/2020. 


\section{HASIL}

Kegiatan Posyandu Lansia Desa Betengsari dilakukan 1 bulan sekali setiap pertengahan bulan. Lansia yang aktif mengikuti posyandu sebanyak 40 lansia. Kegiatan dalam posyandu lansia meliputi penimbangan berat badan, pengukuran tinggi badan, pengukuran tekanan darah, pemeriksaan kesehatan, pengobatan, penyuluhan kesehatan dan pemberian gizi. Pemeriksaan kesehatan meliputi pemeriksaan kadar glukosa, uric acid dan kolesterol yang dilakukan oleh kader desa maupun dari Puskesmas Betengsari. Jumlah responden dalam penelitian ini adalah sebanyak 29 orang. Berikut merupakan data demografi responden dalam penelitian ini.

Tabel 1.

Karakteristik Demografi Responden Penelitian di Posyandu Lansia Desa Betengsari, Kartasura ( $\mathrm{n}=29)$

Karakteristik Responden

1 Jenis Kelamin

Laki-laki

\begin{tabular}{ll} 
& Perempuan \\
\hline 2 Usia &
\end{tabular}

\begin{tabular}{ll}
60 tahun keatas (lansia) \\
\hline $3 \quad$ Riwayat Kolesterol
\end{tabular}

Kolesterol Tinggi (>200 mg/dl)

4 Pola Makan

Tidak diet lemak jenuh

Diet lemak jenuh

5 Pola Aktivitas Fisik

Olahraga

6 Status Merokok

Merokok

3

26

Tidak Merokok

Jumlah

Sumber : Data Primer (2020)
Distribusi Frekuensi

Frekuensi (f) Presentase

(\%) 
Berdasarkan tabel 1 karakteristik responden berdasarkan jenis kelamin menunjukkan mayoritas responden berjenis kelamin perempuan sebanyak 23 responden $\quad(79,3 \%)$ responden berdasarkan usia menunjukkan seluruh responden berusia 60 tahun ketas yaitu sebanyak 29 responden (100\%). Karakteristik responden berdasarkan riwayat kolesterol menunjukkan mayoritas responden memiliki riwayat kolesterol tinggi sebanyak 29 responden (100\%), berdasarkan pola makan menunjukkan mayoritas responden memiliki pola makan diet lemak jenuh sebanyak 26 responden $(89,7 \%)$ dan status merokok yang merokok hanya 3 responden $(10,3 \%)$.

\section{PEMBAHASAN}

\section{Jenis Kelamin}

Pada penelitian ini karakteristik responden berdasarkan jenis kelamin, kadar kolesterol tinggi banyak ditemukan pada kelompok responden pada perempuan sebanyak responden (79,3\%). Pada hasil penelitian ini dominan perempuan yang menderita hiperkolesterolemia. Menurut Irvan (2007) bahwa kekurangan estrogen pada wanita menopause akan menurunkan kolesterol HDL. Hal ini sesuai dengan teori yang menyebutkan bahwa wanita lebih rentan mendapatkan penyakit jantung koroner setelah menopause. Wanita cenderung mempunyai kadar kolesterol yang lebih tinggi setelah menopause yaitu ketika kadar estrogen turun secara dramatis, dan risiko mendapatkan penyakit jantung meningkat (Sandiyani 2012).

Mekanisme estrogen di dalam melindungi jantung adalah karena efek proteksi yang ditimbulkan. Estrogen akan meningkatkan kolesterol baik (HDL) dan menurunkan kolesterol jahat (LDL). Kolesterol jahat (LDL) ini akan menimbulkan plak di dalam darah. Estrogen juga dapat menjalankan fungsi sebagai antioksidan. Peranan estrogen yang lain adalah sebagai pelebar pembuluh darah jantung sehingga aliran darah menjadi lancar dan jantung memperoleh suplai oksigen secara cukup, maka berkuramgnya estrogen pada saat menopause tubuh wanita menjadi rentan terhadap risiko penyakit jantung dan pada wanita menopause, hormon estrogen yang dihasilkan menurun, sehingga resiko terjadinya penumpukan kolesterol pada pembuluh darah arteri akan semakin meningkat sehingga mengakibatkan hiperkolesterol (Khomsan, 2002).

Pada dasarnya laki-laki memiliki resiko yang lebih tinggi akan terjadinya hiperkolesterolemia dibandingkan dengan perempuan Hal ini karena adanya hormon estrogen yang berfungsi melindungi dari plak pembuluh darah. Jumlah hormon estrogen laki-laki lebih sedikit dibanding perempuan. Akan tetapi keduanya memiliki resiko yang sama di rentang usia diatas 60 tahun (Afiah dan Rahayuningsih, 2014).

\section{Usia Responden}

Hasil penelitian karakteristik responden berdasarkan usia, seluruh responden berumur $>60$ tahun sebanyak 29 responden (100\%). Lanjut usia (lansia) memiliki berbagai perubahan fungsi organ, salah satunya yaitu terjadi penurunan elastisitas pada pembuluh darah, yang diakibatkan oleh pengendapan bahanbahan yang bersifat ateroslerotik diantaranya adalah kolesterol (Almatseir, 2011). 
Hal tersebut sesuai dengan penelitian Mei (2016) kejadian hiperkolesterolemia lebih banyak ditemukan pada golongan usia lanjut usia ketimbang kategori umur yang lain. Bertambahnya usia juga menimbulkan penurunan fungsi tubuh. Kecepatan metabolisme pada lansia menurun sekitar 15 - 20\%, disebabkan karena berkurangnya masa otot. Fakta ilmiah menyebutkan bahwa otot menggunakan lebih banyak energi daripada lemak, sehingga lemak menjadi banyak tertimbun di dalam tubuh (Zuhroiyyah et all, 2017). Sejalan dengan bertambahnya usia timbul adanya aritmia jantung, pembuluh darah akan kaku sehingga kehilangan kelenturannya. Endapan lemak menyebabkan terbentuknya ateroskelorsis akan semakin banyak dengan berbagai manifestasi terjadinya hiperkolesterol (Sari et all, 2014).

\section{Riwayat Kolesterol}

Penelitian ini riwayat kolesterol responden seluruhnya adalah memiliki riwayat kolesterol yang tinggi yaitu ada 29 responden (100\%). Dalam penelitian ini terfokus pada penderita kolesterol karena seluruh responden menderita kolesterol dan riwayat kolesterolnya tinggi. Hal tersebut tidak sesuai dengan hasil penelitian yang menemukan bahwa tidak ada hubungan yang signifikan riwayat kolesterol pada kadar kolesterol (Nunung et al., 2018).

Riwayat kejadian kolesterol ini berkaitan dengan usia. Peningkatan kadar kolesterol dalam batas tertentu merupakan hal alami yang terjadi dalam proses penuaan. Kadar kolesterol tinggi meningkat seiring usia pada pria maupun wanita. Pada pria, kadar kolesterol tertinggi terlihat pada usia 45 sampai 54 tahun, sedangkan pada wanita kadar kolesterol tertinggi terlihat pada usia antara 54 sampai 64 tahun. Hal ini sesuai dengan teori yang menjelaskan bahwa pada usia tersebut kemungkinan besar karena efek kumulatif pada sistem kardiovaskuler dari faktor - faktor risiko yang tidak dirawat seperti darah tinggi dan kolesterol meningkat. Dengan kata lain,walaupun arteri kemungkinan besar mengkerut secara bertahap dalam waktu yang lama, efek dari kerusakan hanya menjadi jelas dari usia pertengahan sampai usia tua (Sandiyani, 2012).

\section{Pola Makan}

Hasil penelitian ini menunjukkan bahwa dari 29 lansia yang menderita kolesterol, sebagian besar yaitu 26 responden $(89,7 \%)$ pola makannya diet lemak jenuh. Faktor lain yang dapat mempengaruhi kadar kolesterol adalah pola makan responden yang tidak dikendalikan dimana kebiasaan, komposisi makanan sehari-hari berpengaruh terhadap kadar kolesterol darah seseorang. Selain itu mereka juga tidak minum obat sehingga kadar kolesterol darah cenderung naik.

Menurut Ni Komang et al., (2011) konsumsi lemak jenuh yang baik 10\% dari total energi yang dikonsumsi sehari. Hasil penelitian menunjukkan bahwa baik kasus atau kontrol sebagian besar mengonsumsi lemak jenuh dengan kategori kurang baik yaitu lebih dari 10\% total energi yang dikonsumsi walaupun proporsi pada kasus lebih besar yaitu 59 orang $(90,8 \%)$. Menurut Fauziah (2015) asupan lemak yang lebih dari 30\% dari total kebutuhan energi dapat mempengaruhi terjadinya gangguan metabolisme dalam darah.

\section{Pola Aktivitas Fisik}


Hasil penelitian menunjukkan bahwa 29 responden (100\%) yang menderita kolesterol di Posyandu Lansia Desa Betengsari, semua responden melakukan olahraga. Menurut penelitian Siti et al., (2017) menunjukkan hasil bahwa responden yang memiliki aktivitas fisik tidak memiliki hubungan yang bermakna dengan kadar kolesterol HDL. Sedangkan hasil uji statistik menunjukkan tidak terdapat hubungan yang signifikan antara aktivitas fisik dan status obesitas dengan kadar kolesterol (E'en dan Wulandari, 2018).

Sedangkan berdasarkan penelitian Waloya (2013), Pilch (2015) dan Lopirinzi (2016). Aktivitas fisik memiliki hubungan yang signifikan dengan kadar kolesterol total. Untuk melakukan aktivitas fisik, manusia memerlukan energi yang didapat dari makanan. Jika pemakaian energi menurun, maka makanan yang harusnya dibentuk menjadi energi akan diubah menjadi kolesterol. Ketika melakukan aktivitas fisik, tubuh akan melakukan pembetukan energi yang berupa adenosin triphosphate (ATP) dari makanan yang dikonsumsi. Sehingga makanan yang dikonsumsi tidak banyak dibentuk menjadi kolesterol, akibatnya kadar kolesterol total di dalam tubuh menurun.

Hal ini sejalan dengan teori bahwa setelah melalui proses pencernaan dan penyerapan, makanan akan mengalami pembentukan menjadi Acetyl-CoA yang selanjutnya memasuki siklus krebs untuk proses pembentukan ATP, sehingga proses pembentukan dan transportasi kolesterol ke seluruh tubuh akan menurun yang mengakibatkan kolesterol Low-Density Lipoprotein (LDL) sebagai alat transportasi kolesterol ke seluruh tubuh tidak banyak dibentuk, maka dari itu kadar kolesterol LDL menurun (Pooranfar, 2014). Namun pada penelitian ini aktivitas olahraga yang dilakukan oleh lansia terbatas yaitu ketika ada program senam dari posyandu lansia saja sehingga olahraga yang dilakukan oleh lansia tidak berdapak signifikan pada penurunan kolesterol.

\section{Riwayat Merokok}

Proporsi responden berdasarkan status merokok didapatkan sebagian kecil yang merokok yaitu sebanyak 3 responden $(10,3 \%)$ dan semuanya adalah laki-laki. Menurut data World Health Organization (WHO) tahun 2012 jumlah perokok lakilaki lebih banyak dari pada perokok perempuan yaitu mencapai 67,2\%. Di Indonesia sendiri, prevalensi perokok $16 \mathrm{X}$ lebih tinggi pada laki-laki daripada perempuan (Pusat Data dan Informasi Kementrian Kesehatan RI, 2014).

Berdasarkan hasil penelitian Minarti dkk (2014) terdapat hubungan yang bermakna anatara lama kebiasaan merokok, jumlah rokok yang dihisap setiap hari dan jenis rokok yang dihisaP terhadap kadar LDL. Kebiasaan merokok juga akan meningkatkan kadar kolesterol serum (Devaranavadgi, 2012). Namun pada penelitian ini, jumlah responden perempuan lebih banyak sehingga status merokok adalah semuanya tidak merokok.

Adapun keterbatasan dari penelitian ini adalah peneliti tidak menganalis data lain seperti Indeks Massa Tubuh (IMT) responden yang merupakan salah satu faktor yang dapat mempengaruhi kadar kolesterol di dalam tubuh. Tidak ada konflik kepentingan dalam penelitian ini.

\section{DAFTAR PUSTAKA}

Afiah, dan Rahayuningsih, M.H. (2014). Pengaruh Pemberian Sup Jamur 
Tiram Putih (Pleurotus Ostreatus) terhadap Kadar Kolesterol Total Subjek Penelitian. Journal of Nutrition, 3 (4), 465-472

Almatseir, S. (2011). Prinsip Dasar Ilmu Gizi, Jakarta : Gramedia Pustaka Utama.

Bangun. (2009) Sehat dan Bugar Pada Usia Lanjut Dengan Jus Buah dan Sayuran. Jakarta : Agromedia Pustaka

Devaranavadgi, B. Aski, B. Kashinath, R. (2012). Effect of Cigarette Smoking on Blood Lipid- A Study at Belgaum, Karnataka, India. Global Journal of Medical Research, 12 (6), 1-3.

Depkes. Riset Kesehatan Dasar. (2013). http://www.depkes.go.id/. 2013.

Depkes. Riset Kesehatan Dasar. (2014). http://www.depkes.go.id/. 2014.

Dewanti Sisilia, M dan Teguh Wahyudi. (2011). Uji Aktivitas Antimikroba Infusum Daun Salam (FoliaSyzygiumpoly polyanthum Wight) Terhadap Pertumbuhan Bakteri Escherica Coli Secara In Vitro. Jurnal Medika Planta, Vol. 1 No.4.

E'en, I. Sugiarti dan Wulandari Meikawati. (2018). Hubungan Aktivitas Fisik dan Status Obesitas Dengan Kadar Kolesterol dan Kadar Asam Urat Pada Pegawai Puskesmas Gubug 1 Kabupaten Grobogan. Universitas Muhammadiyah Semarang. http://repository.unimus.ac.id. Diakses pada 19 Juli 2019.

Fauziah Khusnul K. (2015). Hubungan Konsumsi Lemak Dan Aktivitas Fisik Dengan Kadar Kolesterol Darah dan Kadar Low Density Lipoprotein Pada
Pasien Jantung Koroner Rawat Jalan Di Rumah Sakit Umum Daerah Dr. Moewardi. Fakultas Ilmu Kesehatan Universitas Muhammadiyah Surakarta.http://eprint.ums.ac.id. Dikases pada 19 Juli 2019.

Guyton, A. C., Hall, J. E. (2014). Buku Ajar Fisiologi Kedokteran. Edisi 12. Jakarta : EGC

Irvan, A. (2007). Resiko Jantung Koroner Dapat Meningkat Akibat Menopause. http://www.pjnhk.go.id., Diakses pada 19 Juli 2019.

Lina, Listiana. dan Tri Yeni P. (2006). Kadar Kolesterol Total Pada Usia 25-60 Tahun. Journal.um-surabaya.ac.id., Diakses pada 19 Juli 2019.

Lopirinzi PD, Addoh O. (2016). The association of physical activity and cholesterol concentrations across different combinations of central adiposity and body mass index. Heal Promot Perspect. 2016;6(3):128-36. Tersedia dari: http://journals.tbzmed.ac.ir/ HPP

Mamat. (2010). Faktor-Faktor yang Berhubungan Dengan Kadar Kolesterol HDL Di Indonesia (Analisis Data Sekunder IFLS 2007/2008). Fakultas Kesehatan Masyarakat Universitas Indonesia.

Mei, Tsarah A. (2016). Gambaran Kadar Kolesterol Total Pada Lansia Di Panti Sosial Tresna Werdha Sabai Nan Aluih Sicincin. Universitas Andalas. http://scholar.unand.ac.id., Diakses pada 19 Juli 2019.

Minarti, N.S. Ketaren, I dan Hadi, P. D. (20140. Hubungan antara perilaku 
merokok terhadap kadar kolesterol LDL serum pada pekerja CV Julian Pratama Pontianak, 1-17.

Ni Komang W., Pande Putu S. S., Ni Made Y. G. (2011). Konsumsi Lemak Total, Lemak Jenuh, dan Kolesterol Sebagai Faktor Risiko Sindroma Metabolik Pada Masyarakat Perkotaan Di Denpasar. Jurnal Gizi Klinik Indonesia, Vol. 7 No. 3.

Nunung Sri M., Agus Hendra. A. R., Raudatul Jannah. (2018). Faktor Resiko Kadar Kolesterol Darah Pada Pasien Rawat Jalan Penderita Jantung Koroner Di RSUD Meuraxa. Jurusan Gizi Poltekkes Kemenkes Aceh. http://garuda.risetdikti.go.id. Diakses pada 19 Juli 2019.

Pilch WB, Mucha DM, Pałka TA, Suder AE, Piotrowska AM, Tyka AK, dkk (2015). The influence of a 12-week program of physical activity on changes in body composition and lipid and carbohydrate status in postmenopausal women. 2015;14(4):231-7.

Pusat Data dan Informasi Kementrian Kesehatan RI. (2014). Perilaku Merokok Masyarakat Indonesia Berdasarkan Riskesdas 2007 dan 2017. Kemenkes RI

Puspito, H. 2014. Studi Komparasi Efektivitas Pemberian Madu Labu Siam Labu Siam Dan Madu Terhadap Tekanan Darah Penderita Hipertensi Primer Di Dusun Pundung Nogotirto Gamping Sleman Yogyakarta. SKRIPSI tidak di publikasikan.

Pooranfar S, Shakoor E, Shafahi MJ, M.Salesi, Karimi MH, Roozbeh J, dkk.(2014).
The Effect of Exercise Training on Quality and Quantity of Sleep and Lipid Profile in Renal Transplant Patients: A Randomized Clinical Trial. Int J Organ Transplant Med. 2014;5 (4).

Khomsan, A.(2008). Sehat Itu Mudah Wujudkan Hidup Sehat Dengan Makanan Tepat. Jakarta : Hikmah PT Mizani Publika

Sandiyani, Z. (2012). Pengaruh Pemberian Air Rebusan Daun Salam Terhadap Kadar Kolesterol DarahPada Usia Dewasa Di Wilayah Kerja Puskesmas Wirobrajan Yogyakarta. Skripsi . Tidak Dipublikasikan. Sekolah Tinggi Ilmu Kesehatan 'Aisyiyah Yogyakarta.

Sari, D.Y. Prihatini, S dan Bantas, K. (2014). Asupan Serat Makanan dan Kadar Kolesterol - LDL berusia 25-65 Tahun di Kelurahan Kebon Kalapa, Bogor. Panel Gizi Makan 37(1), 51-58.

Septianggi, F. N., Mulyati T., dan K.H.S. (2013). Hubungan Asupan Lemak dan Asupan Kolesterol dengan Kadar Kolesterol Total pada Penderita Jantung Koroner Rawat Jalan di RSUD Tugurejo, 2 (Nov),13-20.

Sri Ujiani. (2015). Hubungan Antara Usia dan Jenis Kelamin Dengan Kadar Kolesterol Penderita Obesitas RSUD Abdul Moeloek Provinsi Lampung. Jurnal Analis Kesehatan Poltekkes Tanjungkarang, Vol. 4 No. 1.

Syafiudin, A. 2011. Daun Salam Ahli Atasi Kolesterol. http://fachirlt.blogspot.com/2011/0 7/daun-salam-ahli-atasikolesterol.html diakses tanggal 16 Desember 2013 
Stapleton A. Phoebe, et al. (2010). Hypercholestrolemiaans Microvascular Dysfunction : International strategies, Journal of Inflammation. 7:54. Diakses pada 25 Juli 2019, http://www.journalinflammation.com/content.2019

Sumono, A. dan Agustin, W. S. D. (2008). The User Of Bay Leaf (Eugenia Polyantha Wight) in dentistry. Dentistry Journal, Vol. 41 No. 3.

Waloya T, Rimbawan, Andarwulan N. (2013). Hubungan antara konsumsi pangan dan aktivitas fisik dengan kadar kolesterol darah pria dan wanita dewasa di Bogor. J Gizi dan Pangan. 2013;8(1):9-16.

Widianti dan Proverawati. (2010). Senam Kesehatan. Yogyakarta : Nuha Medika

Wulan Septianingrum. (2014). Pengaruh Pemberian Air Rebusan Daun Salam Terhadap Kadar Kolesterol Pada Lansia Hiperkolesterol di Trimulyo Sleman. Sekolah Tinggi Ilmu Kesehatan 'Aisyiyah Yogyakarta.

WHO. (2012). World Health Statistic 2012. France. World Health Organization.

Zuhroiyyah, Siti., Sukandar, Hadyana., Sunaryo Barki S. (2017). Hubungan Aktivitas Fisik dengan Kadar Kolesterol Total, Kolesterol LowDensity Lipoprotein pada Masyarakat Jatinangor. Fakultas Kedokteran Universitas Padjadjaran. 